\title{
The expression of oestrogen receptor (ER)- $\beta$ and its variants, but not ERo, in adult human mammary fibroblasts
}

\author{
C Palmieri, S Saji ${ }^{1}$, H Sakaguchi², G Cheng ${ }^{2}$, A Sunters, M J O'Hare ${ }^{3}$, M Warner ${ }^{2}$, \\ J-Å Gustafsson ${ }^{2}$, R C Coombes and E W-F Lam \begin{abstract}
Hammersmith Hospital, Du Cane Road, London W12 ONN, UK
${ }^{1}$ Department of Surgery, Breast Oncology Unit, Tokyo Metropolitan Hospital, 113-8677, Tokyo, Japan

2Departments of Biosciences and Medical Nutrition, Karolinska Institute, NOVUM, S-141 86 Huddinge, Sweden

${ }^{3}$ University College London Breast Cancer Laboratory, Department of Surgery, Royal Free and University College Medical School, Riding House
\end{abstract} \\ Cancer Research-UK Laboratories and Section of Cancer Cell Biology, Department of Cancer Medicine, MRC Cyclotron Building, Imperial College, \\ Street, London W1W 7EJ, UK
}

(Requests for offprints should be addressed to E W-F Lam; Email: eric.lam@imperial.ac.uk)

\begin{abstract}
Whilst oestrogen receptor (ER)- $\alpha$ and ER $\beta$ have been shown to be important in the development of the mammary gland, the cell-specific expression pattern of these two receptors within the human breast is not clear. Although it is well established that in the developing rodent mammary gland stromal ER $\alpha$ mediates the secretion of growth factors which stimulate the proliferation of the ductal epithelium, the expression of $E R \alpha$ in human adult breast stromal fibroblasts is controversial, and the expression of ER $\beta$ has not been properly defined. In the present study, we have evaluated the expression of ER $\alpha$ and ER $\beta$ by immunohistochemistry in normal tissue samples, and in purified human breast fibroblasts by Western blotting, RT-PCR analysis and ligand-binding sucrose gradient assay. Our data clearly demonstrated that $E R \beta$ variants, including ER $\beta 1, E R \beta 2, E R \beta 5$, ER $\beta \delta$ and ER $\beta$ ins, but not $E R \alpha$, are expressed in human adult mammary fibroblasts. These results are supported by the findings that an ER $\beta$-selective ligand, BAG, but not the ER $\alpha$ high-affinity ligand oestradiol, can induce fibroblast growth factor-7 release and activate transcription from an oestrogen-responsive element promoter in these adult human mammary fibroblasts. Together, these observations revealed that, in the adult breast and in breast cancer, the proliferative signals derived from the stroma of adult mammary glands in response to oestrogen are not mediated by $\mathrm{ER} \alpha$ and provide new insights into the nature of stromal-epithelial interactions in the adult mammary gland. In addition, the expression of these ER $\beta$ variants in cells where there is no ER $\alpha$ suggested that these ER $\beta$ splice forms may have functions other than that of modulating $E R \alpha$ activity.
\end{abstract}

Journal of Molecular Endocrinology (2004) 33, 35-50

\section{Introduction}

Oestrogen (e.g. oestradiol) plays a crucial role in regulating the growth and differentiation of the normal mammary gland and has an important role in the development and progression of breast cancer (Girdler \& Brotherick 2000). The actions of oestrogen are mediated by its interaction with two oestrogen receptors, $\mathrm{ER} \alpha$ and $\mathrm{ER} \beta$, which are ligand-activated nuclear transcription factors and members of the steroid/nuclear receptor superfamily (Kuiper et al. 1996, Parker 1998, Nilsson et al.
2001). Although $\operatorname{ER} \alpha$ and $\operatorname{ER} \beta$ are structurally similar (Brzozowski et al. 1997), there are significant differences in their ligand affinities and interaction with the transcriptional machinery, which result in important physiological and pharmacological differences in the signalling of the two receptors. Differential activation of the oestrogen-responsive element (ERE)-regulated and the activator protein1 (AP-1)-controlled reporter genes by $\mathrm{ER} \alpha$ and ER $\beta$ has been documented (Paech et al. 1997).

There are several mechanisms through which oestrogen stimulates growth of mammary 
epithelium. One mechanism, which is crucial in the developing mammary gland, is the indirect effect of oestrogen on the mammary epithelium. In this case, oestrogen induces the mammary stroma to secrete growth factors, which in turn stimulate epithelial proliferation (Cunha et al. 1997). There is a considerable body of evidence showing that stromal ER $\alpha$ is involved in rodent mammary gland morphogenesis (Haslam \& Shyamala 1981, Cunha et al. 1997). Recent studies in mice using chimeric tissue recombinations between $\mathrm{ER} \alpha$ null and normal mice indicate that oestrogen-mediated proliferation of epithelial cells is dependent upon the presence of ER $\alpha$ in mouse mammary stromal cells, but not in epithelial cells (Yang et al. 1995, Bocchinfuso \& Korach 1997). However, this is not an absolute requirement since the stroma from $\mathrm{ER} \alpha$ null mice can support epithelial growth if oestrogen and progesterone are administered (Yang et al. 1995). Consistent with this notion is a recent immunohistochemical study on mouse transplanted human organoids showing that $\mathrm{ER} \alpha$ is expressed in luminal epithelium but not the stroma (Parmar et al. 2002).

The adult mammary gland undergoes morphogenesis and remodelling throughout reproductive life. Morphogenesis is regulated by circulating steroids and polypeptide hormones, as well as by local epithelial-mesenchymal signals. The production and release of mesenchymal factors are under endocrine control. For example, the hepatocyte growth factor (HGF)/scatter factor (SF) promotes ductal outgrowth and tubule formation in the mammary gland (Niranjan et al. 1995), and the secretion of $\mathrm{HGF} / \mathrm{SF}$ from the stroma has been shown to be increased by oestrogen (Sunil et al. 2002). Fibroblast growth factor (FGF7) (also termed keratinocyte growth factor (KGF)) is also another important mesenchymal-derived epithelial growth factor that has been shown to be regulated by oestrogen; however, there are species differences in its function on epithelial cells and its regulation by oestrogen. In humans, FGF7 stimulates both normal and malignant breast cancer epithelial cell proliferation (Palmieri et al. 2003). One report has indicated that the expression of FGF7 is not affected by oestrogen in normal breast stromal cells but is stimulated by oestrogen in stromal cells from breast cancers (Zhang et al. 1998). Administration of FGF7 to rats causes ductal proliferation, whilst in mice it results in cystic ducts (Yi et al. 1995). In mice, oestrogen was found to cause an increase in FGF7 in the mammary gland in vivo, but response was slow, and the dose needed was higher than that needed for growth of the uterus (Pedchenko \& Imagawa 2000).

Although the evidence for the presence of ER $\alpha$ in the developing mammary stroma is strong, there is some question about which of the ERs is expressed in the stroma of the adult gland. ER $\alpha$ has been detected in stromal cells derived from tissues of fetuses, infants and young female individuals (Boyd et al. 1996, Keeling et al. 2000) but not stromal cells from adult samples (Boyd et al. 1996). By in situ hydridization, Sasano et al. (1999) detected $\mathrm{ER} \alpha$ mRNA predominantly in ductal epithelial cells and also in some stromal cells. Others have also shown by immunohistochemical staining that there is a lack of ER $\alpha$ in both cancerous and normal human breast stromal cells (Walker et al. 1992, Leygue et al. 1999). Although ER $\beta$ is less well studied that $\mathrm{ER} \alpha$, there is evidence that $\mathrm{ER} \beta$ is expressed in both epithelium and stroma (Crandall et al. 1998, Palmieri et al. 2002).

In the present study, we have investigated the presence of $\operatorname{ER} \alpha$ and $\operatorname{ER} \beta$ in breast stroma from normal breast tissue and from breast cancer. We purified fibroblasts from normal and malignant breasts and found that $\mathrm{ER} \beta 1$, and its slice variants ER $\beta c x$ (Ogawa et al. 1998) and $\operatorname{ER} \beta \delta 5$, but not $\mathrm{ER} \alpha$, are expressed in these human breast fibroblasts. Furthermore, treatment of these fibroblasts with interleukin (IL)-1 $\beta$ and ER $\beta$-specific agonist are more effective than oestrogen in stimulating fibroblasts to secrete the growth factor FGF7.

\section{Materials and methods}

\section{Tissue samples}

Human breast samples were obtained with the approval of the local ethics committee and consent from women who underwent breast reduction mammoplasty and surgery for carcinoma of the breast at Charing Cross Hospital and Central Middlesex Hospital, London, UK.

\section{Immunohistochemical staining}

Paraffin sections of breast tissue were obtained from the histopathology archive at Charing Cross 
Hospital, London. In all the immunostaining experiments, paraffin sections $(4 \mu \mathrm{m})$ were dewaxed in xylene and rehydrated through graded alcohol. Endogenous peroxidase was blocked by incubation for $15 \mathrm{~min}$ with a solution of $0.6 \%$ hydrogen peroxide and antigens were retrieved by microwaving sections in $1 \mathrm{mM}$ citrate buffer $(\mathrm{pH} 6 \cdot 0)$ for $20 \mathrm{~min}$ at $800 \mathrm{~W}$. Tissue sections were incubated for $10 \mathrm{~min}$ at room temperature with antibody diluent containing 5\% normal rabbit serum, $0 \cdot 1 \%$ bovine serum albumin and $0 \cdot 1 \%$ sodium azide in phosphate-buffered saline (PBS). For ER $\beta$ immunostaining, a rabbit anti-human $\operatorname{ER} \beta$ polyclonal (06-629) antibody from Upstate Biotechnology (Lake Placid, NY, USA) (1/100 dilution in antibody diluent) was applied to sections and incubated overnight at $4{ }^{\circ} \mathrm{C}$. ER $\beta \mathrm{cx}$ was detected by a specific antibody described recently (Saji et al. 2002). For ER $\alpha$ staining, monoclonal mouse anti-ER $\alpha$ (1D5; Santa Cruz Biotechnology, Santa Cruz, CA, USA) was applied at a dilution of $1 / 500$ in antibody diluent and the sections incubated overnight at $4{ }^{\circ} \mathrm{C}$. After incubation with the primary antibodies, the sections were rinsed in PBS with $0 \cdot 05 \%$ Tween 20 prior to addition of the appropriate peroxidase-conjugated secondary antibody in PBS. As secondary antibodies, peroxidase-conjugated rabbit anti-mouse $\mathrm{IgG}$ (Dako, Ely, UK) and goat anti-rabbit IgG (Sigma, Poole, Dorset, UK) were used at dilutions of 1:100. After incubation for $1 \mathrm{~h}$ at room temperature the secondary antibodies were washed off with PBS with $0 \cdot 05 \%$ Tween 20. Colour staining was developed with hydrogen peroxide and 3,3'diaminobenzidine tetrahydrochloride (DAB; Dako). After colour development, the sections were also counterstained with Mayer's haematoxylin, dehydrated through graded alcohol to xylene, and mounted with Pertex (Histolab, Havershill, UK).

\section{Breast fibroblast purification and culture}

Breast fibroblasts were prepared from reduction mammoplasty and breast carcinoma tissues as described previously (Gomm et al. 1995). The tissues were first assessed by histopathologists to ascertain the exact pathological status before being used for breast fibroblast preparations. Briefly, $0.5 \mathrm{~cm}^{2}$ breast tissue was digested overnight with $1 \mathrm{mg} / \mathrm{ml}$ collagenase (Sigma) and $1 \mathrm{mg} / \mathrm{ml}$ hyaluronidase (Sigma) in RPMI 1640 (Gibco-BRL,
Life Technologies Inc., Paisley, UK) plus 5\% fetal calf serum (FCS) at $37^{\circ} \mathrm{C}$, followed by centrifugation at $150 \boldsymbol{g}$ for $5 \mathrm{~min}$. After removing the lipid layer, the tissue suspension was subjected to three sedimentations at $1 \boldsymbol{g}$ (or under gravity) to enrich for the ductal and lobular elements. The supernatants containing single cells (including blood cells, fibroblasts and endothelial cells) were removed and cultured in Dulbecco's modified Eagle's medium (DMEM) (Gibco-BRL, Life Technologies Inc.) supplemented with 10\% FCS, $2 \mathrm{mM}$ glutamine, $100 \mathrm{U} / \mathrm{ml}$ penicillin and $0 \cdot 1 \mathrm{mg} / \mathrm{ml}$ streptomycin to positively select for stromal cells. The blood cells in the cell suspension were eliminated by three rounds of depletion using anti-common acute lymphoblastic leukaemia antigen (CALLA/CD10; Sera-Lab, Loughborough, UK) conjugated to $4.5 \mu \mathrm{m}$ Dynabeads (Dynal, Bromborough, UK) according to the manufacturer's protocol. Dynabead-conjugated rat monoclonal anti-epithelial membrane antigen was then used to eliminate epithelial and myoepithelial cells as described (Gomm et al. 1995). The purified breast fibroblasts were then expanded and used for RNA and protein preparation. One of the fibroblast lines (line 8) is conditionally immortalized and has been described previously (O'Hare et al. 2001).

\section{RNA preparation and cDNA production by RT}

Total RNA was isolated using the RNAeasy kit (Qiagen, Crawley, UK) and quantified by absorbance at $260 \mathrm{~nm}$. Total RNA (2 $\mu \mathrm{g})$ was reverse transcribed in a $12 \mu$ reaction mixture composed of $10 \mathrm{U}$ MMLV reverse transcriptase (Gibco-BRL, Life Technologies Inc.), $2 \mathrm{mM}$ dNTPs, $6.7 \mathrm{mM}$ $\mathrm{MgCl}_{2}$ and $5 \mu \mathrm{M}$ random hexamer primers. The mixture was incubated at $40{ }^{\circ} \mathrm{C}$ for $60 \mathrm{~min}$, followed by heating at $95^{\circ} \mathrm{C}$ for $10 \mathrm{~min}$.

\section{PCR}

PCR was carried out using the Gene Amp PCR System 2400 or 7700 gene amplifier (Perkin-Elmer, Beaconsfield, UK). The PGR of $50 \mu$ consisted of $3 \mu \mathrm{l} \mathrm{cDNA}$ (corresponding to $500 \mathrm{ng}$ RNA),

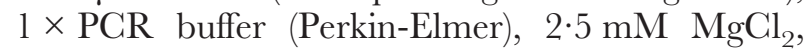
$0.2 \mathrm{mM}$ dNTPs, 0.5 units Taq polymerase (Perkin-Elmer) and $1 \mu \mathrm{M}$ of each of the sequence specific primers. At each cycle, the PGR was denatured at $94^{\circ} \mathrm{C}$ for $30 \mathrm{~s}$, annealed at specific 
temperature/time and extended at $72{ }^{\circ} \mathrm{C}$ for $60 \mathrm{~s}$. The final extension was at $72{ }^{\circ} \mathrm{C}$ for $3 \mathrm{~min}$ at the completion of the last cycle. The nucleotide sequences, annealing temperatures, reaction cycles and predicted sizes of the cDNA products of the primers used and names were as follows.

$\beta$-actin (1) PGR: forward 5'-GTGGACGTC GCGCGATGCTG-3'; reverse 5'-CGTCACGGA GCGCGGCTACAG-3' (58 ${ }^{\circ} \mathrm{C}, 35$ cycles, 500 bp).

ER $\alpha$ PGR: EX2U forward 5'-GGAGACATGA GAGCTGCGAC-3'; EX4L reverse 5'-CGAGC AGCATGTCGAAGATC- $3^{\prime} \quad\left(58^{\circ} \mathrm{C}, 40\right.$ cycles, 292 bp).

ER $\beta$ PCR: forward 5'-TGTTACTGGTCGAG GTTCAAAGAGG-3'; reverse 5'-AGCGACAC TTGACGATTCGCAC-3 ${ }^{\prime} \quad\left(60^{\circ} \mathrm{C}, 40\right.$ cycles, $200 \mathrm{bp})$.

ER $\beta$ WT (wild type)/ $\beta$ ins PGR: forward (LBD U) 5'-GAGCTCAGCCTGTTCGACG-3'; reverse (LBD L) 5'-GGCGTTGACACAGAGATATTG-3' $\left(57^{\circ} \mathrm{C}\right.$, 38 cycles, $247 \mathrm{bp}$ for WT and $300 \mathrm{bp}$ for $\beta$ ins).

ER $\beta$ WT/ $\delta 5$ PCR: forward $\delta 55^{\prime}$-ATGA TGATGTCGCTGACGAAG-3'; reverse LBD L 5'-GGGCTTGACACAGAGATATTC- $3^{\prime} \quad\left(57^{\circ} \mathrm{C}\right.$, 38 cycles, $327 \mathrm{bp}$ for WT and $188 \mathrm{bp}$ for $\delta 5)$.

$\mathrm{ER} \beta \quad \mathrm{WT} / \beta \mathrm{cx} / \beta 5 \quad$ PCR: forward 5'-CGATGCTTTGGTTTGGGTGAT-3'; reverse (1 L) 5'-GCGCTCTTTGGTTTTACTGTC-3'; reverse (2 L) 5'-CTTTAGGCGACGGAGTTG ATT-3' $\left(57^{\circ} \mathrm{C}, 38\right.$ cycles, $268 \mathrm{bp}$ for WT, $214 \mathrm{bp}$ for $\beta \mathrm{cx}$ and $295 \mathrm{bp}$ for $\beta 5$ ).

Cytokeratin 19 PGR: forward 5'-TCGGCGC GCTTTGTGTCGCTCGT-3'; reverse 5'-AG CATGCTTCGGGTTCTGGTGG-3' $\left(69^{\circ} \mathrm{C}, \quad 30\right.$ cycles, 488 bp).

$\beta$-actin (2) PGR: forward 5'-CTGGCACGA CACGTTCTAC-3'; reverse 5'-GGGGACAGT GTGGGTGAC-3' $\left(58{ }^{\circ} \mathrm{C}, 35\right.$ cycles, 237 bp).

All PCR products were resolved on $2 \%$ agarose gel by electrophoresis in Tris-acetate-EDTA buffer in the presence of $0.5 \mu \mathrm{g} / \mathrm{ml}$ ethidium bromide. The DNA bands were visualised in the presence of u.v. illumination.

\section{Western blot analysis and antibodies}

Whole cell extracts were prepared by lysing cells with four times packed cell volume of lysis buffer (1\% Nonidet P-40, $100 \mathrm{mM} \mathrm{NaCl,} 20 \mathrm{mM}$ Tris, $\mathrm{pH}$ 7•4, $10 \mathrm{mM} \mathrm{NaF}, 1 \mathrm{mM}$ sodium orthovanadate and protease inhibitors ('Complete' purchased from Roche, Lewes, UK) on ice for $15 \mathrm{~min}$. Protein yield was quantified by Bio-Rad Dc protein assay kit (Bio-Rad, Hemel Hempstead, UK). One hundred micrograms of lysate were separated by SDSPAGE, transferred to nitrocellulose membranes and recognised by specific antibodies. The ER $\beta$ (06-629) and ER $\alpha$ (ID5) antibodies used for immunostaining did not give the best results for Western blotting, and the ER $\alpha(\mathrm{F}-10)$ antibody and the polyclonal $\operatorname{ER} \beta$ (LBD) were used instead for Western blotting. The mouse monoclonal ER $\alpha$ (F-10) antibody and the anti-actin polyclonal antibody were purchased from Santa Cruz Biotechnology. The rabbit polyclonal ER $\beta$ (LBD) and ER $\beta c x$ antibodies have been described previously (Saji et al. 2000, 2002) and were raised against the ligand-binding domain of $\mathrm{ER} \beta 1$ protein and the $\mathrm{C}$-terminus of ER $\beta \mathrm{cx}$ respectively. The antibodies were detected using horseradish peroxidase-linked goat anti-mouse or anti-rabbit IgG (Dako) and visualised by the enhanced chemiluminescent detection system (Amersham Pharmacia Biotech, Amersham, Bucks, UK.)

\section{Sucrose density gradient assay}

Sucrose density gradient assay was performed essentially as described previously (Jensen et al. 1968, Palmieri et al. 2002). Cell pellets frozen on liquid nitrogen were pulverised in a dismembrator (Braun Melsungen, Melsungen, Germany) for $45 \mathrm{~s}$ at 1800 r.p.m. Pulverised cells $(100 \mu \mathrm{g} / \mathrm{ml})$ were added to a buffer consisting of $10 \mathrm{mM}$ Tris- $\mathrm{HCl}$, $\mathrm{pH} 7.5,1.5 \mathrm{mM}$ EDTA and $5 \mathrm{mM}$ sodium molybdate. Cytosol was obtained by centrifugation of the homogenate at $75000 \boldsymbol{g}$ for $1 \mathrm{~h}$ in a $70 \mathrm{Ti}$ rotor (Beckman Instruments, High Wycombe, UK) at $4{ }^{\circ} \mathrm{C}$. Cell extracts were incubated for $2 \mathrm{~h}$ at $0{ }^{\circ} \mathrm{C}$ with $10 \mathrm{nM} \quad\left[{ }^{3} \mathrm{H}\right]$ oestradiol (Amersham International, Amersham, Bucks, UK) in the absence or presence of 50-fold excess of unlabelled oestradiol (Sigma) as described previously (Saji et al. 2000), and the unbound oestradiol was removed with dextran-coated charcoal. Samples $(100 \mu \mathrm{l})$ were layered on $4 \mathrm{ml}$ sucrose density gradients (10-30\% (w/v) sucrose in $10 \mathrm{mM}$ Tris- $\mathrm{HCl}, 1.5 \mathrm{mM}$ EDTA, $1 \mathrm{mM}$-monothioglycerol (Sigma) and $10 \mathrm{mM} \mathrm{KCl}$ ) and centrifuged for $16 \mathrm{~h}$ at $300000 \mathrm{~g}$ in an $\mathrm{SW}-60 \mathrm{Ti}$ rotor (Beckman Instruments) at $4{ }^{\circ} \mathrm{C}$. Successive $100 \mu \mathrm{l}$ fractions were collected from the 
bottom by paraffin oil displacement and assayed for radioactivity by liquid scintillation counting. For Western blotting, fractions were first precipitated with trichloroacetic acid, then resuspended in methanol and incubated on dry ice for $30 \mathrm{~min}$. The protein was recovered by centrifugation. Pellets were dissolved in SDS sample buffer, resolved by SDS-PAGE and subjected to Western blot analysis.

\section{FGF7 release and transfection assays}

Purified human breast fibroblasts were normally cultured in DMEM with $10 \%$ FCS, $2 \mathrm{mM}$ glutamine, $100 \mathrm{U} / \mathrm{ml}$ penicillin and $0.1 \mathrm{mg} / \mathrm{ml}$ streptomycin. To assess the effects of different growth factors and ligands on the production of FGF7, the purified breast fibroblasts were incubated with different cytokines and ER ligands in breast culture medium (BCM) consisting of 1:1 mix of DMEM (without phenol red) and Ham's F12 supplemented with $15 \mathrm{mM}$ HEPES, $2 \mathrm{mM}$ glutamine, $5 \mu \mathrm{g} / \mathrm{ml}$ insulin, $10 \mu \mathrm{g} / \mathrm{ml}$ apo-transferrin, $100 \mu \mathrm{M}$ ethanolamine, $1 \mu \mathrm{g} / \mathrm{ml}$ hydrocortisone, $10 \mathrm{ng} / \mathrm{ml}$ epidermal growth factor, $100 \mathrm{U} / \mathrm{ml}$ penicillin, $0.1 \mathrm{mg} / \mathrm{ml}$ streptomycin, $50 \mathrm{U} / \mathrm{ml}$ polymyxin $\mathrm{B}$ and $2.5 \mu \mathrm{g} / \mathrm{ml}$ amphotericin (all from Sigma) (Gomm et al. 1995, 1997). The amount of FGF7 produced by the fibroblasts in the culture medium was measured using the human KGF Quantikine Kit (R\&D Systems, Abingdon, UK) according to the manufacturer's protocol. The human KGF Quantikine Kit was an ELISA-based quantification assay, and the absorbance was measured at a wavelength of $450 \mathrm{~nm}$ within $30 \mathrm{~min}$ using a 550 plate reader (Bio-Rad). IL-1 $\beta$ was purchased from R\&D Systems. Oestradiol, tamoxifen and kaempferol (3,4',5,7-tetrahydroxyflavone) were obtained from Sigma and ICI 182,780 from Trocris Cookson Inc. (St Louis, $\mathrm{MO}$, USA). The ER $\beta$-selective agonist BAG (L-851 057) (Cheng et al. 2004) was supplied by Merck, West Drayton, UK. All the ER ligands were prepared in ethanol and added at the concentrations indicated.

For transfection assays, an ERE-driven chloramphenicol acetyltransferase (CAT) gene reporter plasmid was co-transfected with a pSG5- $\beta$ galactosidase transfection control into the human mammary fibroblasts cultured in BCM using the calcium phosphate precipitation method (Lam et al. 1995). These plasmids have all been described previously (Ali et al. 1993, Chen et al. 1999). The transfected human mammary fibroblasts were then treated as described for FGF7 release assay and harvested for CAT and $\beta$-galactosidase after 3 days. The CAT expression was quantified using a CAT ELISA kit (Roche Diagnostics $\mathrm{GmbH}$ ) as described by the manufacturer.

\section{Results}

\section{Immunohistochemical localisation of ER $\alpha$ and $E R \beta$ in human breast tissues}

Immunohistochemical staining of formalin-fixed paraffin-embedded sections of normal human breast tissue are shown in Fig. 1. As previously reported (Jensen et al. 2001), ER $\alpha$ was expressed primarily in the epithelium, but not in the stroma (Fig. 1A), while staining for $\operatorname{ER} \beta$ was observed in both the epithelium and stroma (Fig. 1B and C). This staining pattern was not detected with a non-specific control antibody (Fig. 1D and E) and the staining was blocked by 100 -fold excess of the peptide used as antigen (Fig. 1F). The ER $\beta$ antibody used in Fig. $1 \mathrm{~A}-\mathrm{F}$ was raised against an N-terminal peptide common to both ER $\beta 1$ and ER $\beta c x$. In order to investigate the cellular localization of ER $\beta c x$, a specific antibody raised against the unique amino acid sequence coded for by the ER $\beta$ cx-specific exon was used. The result showed that as shown in Fig. $1 \mathrm{G}$ and H ER $\beta c x$ is also present in both epithelial cells and fibroblasts of breast (Fig. 1I-L).

\section{Expression of ER $\alpha$ and ER $\beta$ mRNA in human breast fibroblasts}

The expression of $\operatorname{ER} \alpha$ and $\operatorname{ER} \beta$ mRNA was investigated by RT-PCR analysis. RNA was extracted from a panel of human breast fibroblasts purified from normal breast tissue derived from reduction mammoplasty as well as fibroblasts from women who had undergone surgery for malignant breast tumours. The panel consisted of seven normal (lines 1-7) and six malignant (lines 9-14) fibroblasts, as well as an immortalised human fibroblast cell line (line 8) which was derived from a reduction mammoplasty. For comparison, we also included the malignant breast epithelial cell lines MCF-7, MDA-MB-231 and T47D for ER $\alpha$ specific RT-PCR, and MCF-7 and MDA-MB-231 for ER $\beta$ RT-PGR (Fig. 2). $\beta$-actin was used as a 


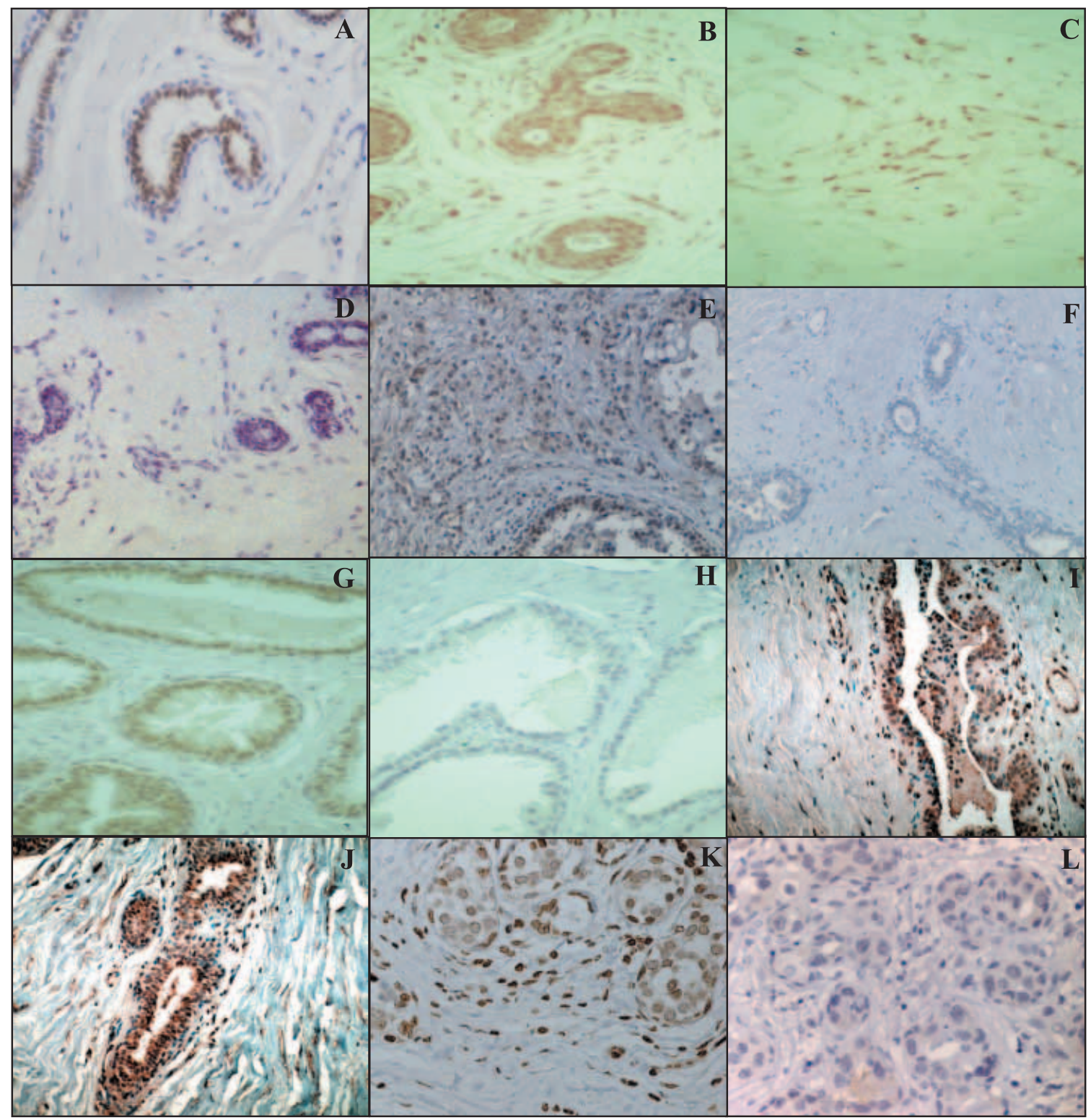

Figure 1 Immunostaining of normal human breast tissues for ER $\alpha$ and ER $\beta$ expression. Representative photomicrographs of immunohistochemical staining of breast sections using DAB as substrate. All micrographs were at $200 \times$ magnification unless indicated. (A) Normal human breast tissue was stained with anti-ER $\alpha$ (1D5) antibody. Positive staining was detected in epithelial cells only. (B) Normal human breast tissue was stained with an anti-ER $\beta$ (06-629) antibody. Staining is observed in the ductal epithelial cells and stromal fibroblasts. (C) Normal human breast stroma was stained with the anti-ER $\beta$ antibody. (D) Normal human breast tissue was stained with an unrelated antibody, demonstrating no ductal epithelial and stromal staining. (E) Normal human breast tissue was stained with the anti-ER $\beta$ antibody, showing positive staining for epithelial cells and some stromal cells. (F) Normal breast tissue (as in E) was stained with the anti-ER $\beta$ antibody in the presence of antigenic peptides. (G) Control normal prostate tissue was stained with the anti-ER $\beta$ antibody, showing positive staining for epithelial cells only. $(\mathrm{H})$ Normal prostate tissue was stained with the anti-ER $\beta$ antibody in the presence of the antigenic (blocking) peptides, showing no sign of staining. (I) Normal human breast tissue was stained the anti-ER $\beta$ antibody (LBD) (100×magnification). (J) Normal human breast tissue was stained with an anti-ERßcx-specific antibody (Saji et al. 2002) (100xmagnification). (K) Normal human breast tissue was stained with the anti-ERßcx-specific antibody. (L) Normal human breast tissue was stained with the anti-ER $\beta c x$-specific antibody in the presence of the antigenic peptides, showing little sign of staining. Nuclear localisation is observed in all the positive staining. 


\section{\begin{tabular}{l|l|l|l|l|l|l|l}
1 & 2 & 3 & 4 & 5 & 6 & 7 & 8 \\
\hline
\end{tabular}}

ER $\alpha$

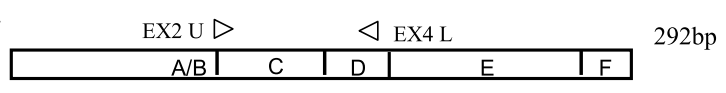

\section{ER $\beta$}
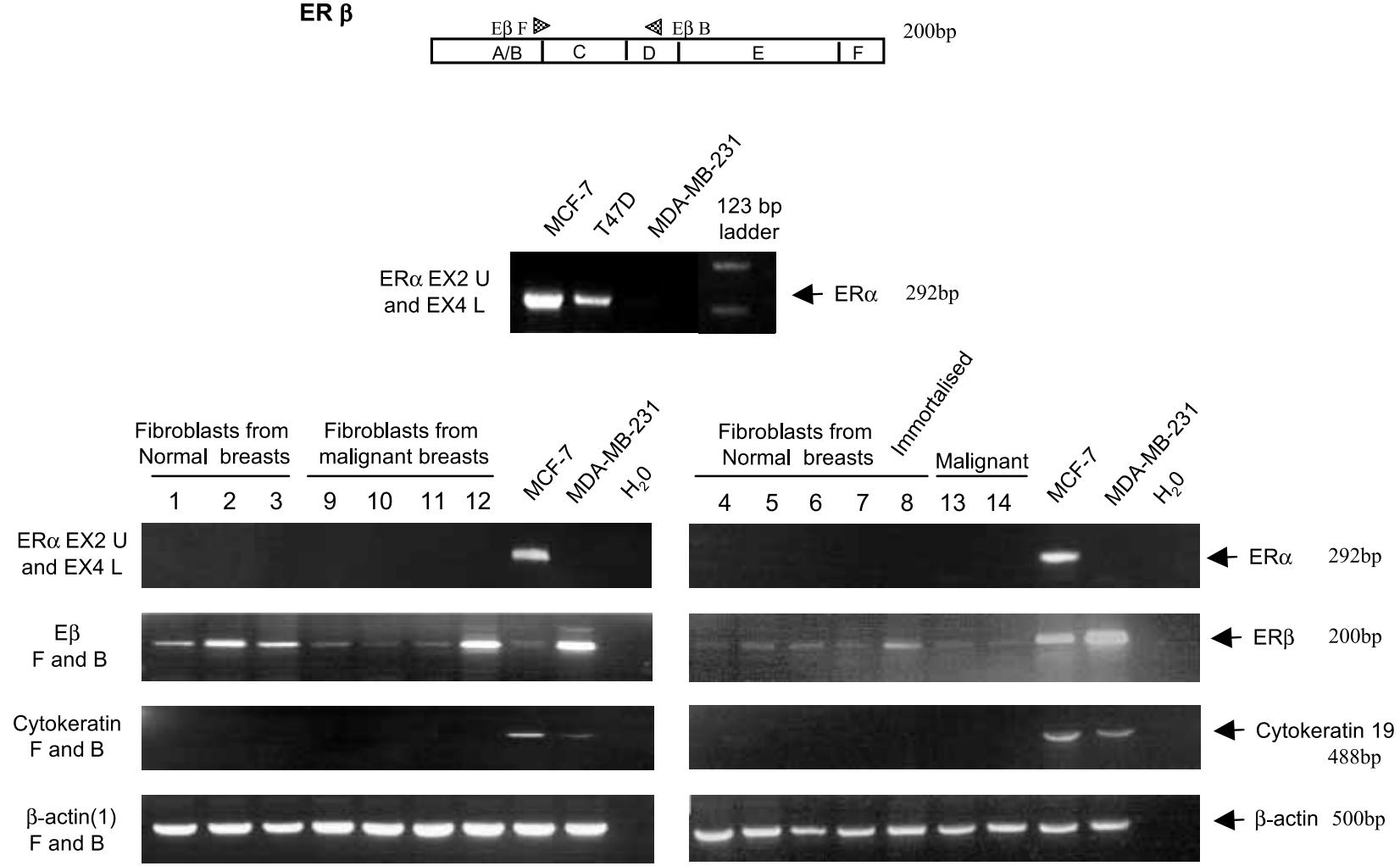

Figure 2 Expression of $\mathrm{ER} \alpha$, ER $\beta$, cytokeratin 19 and $\beta$-actin mRNA in purified breast fibroblasts and breast epithelial cancer cell lines. Total RNA extracted from 14 normal and malignant breast fibroblasts, and the epithelial cancer cell lines MCF-7 and MDA-MB-231 was reverse transcribed and analysed for the expression of ER $\alpha$, ER $\beta$, cytokeratin 19 and $\beta$-actin mRNA by PCR using the primers shown. The ER-positive cell line T47D was also included as an extra positive control for ER $\alpha$ PCR. Schematic diagrams of the exons and functional domains of $\mathrm{ER} \alpha$ and ER $\beta$ are shown in the upper panel.

control for cDNA synthesis, PGR efficiency and gel loading.

The ER $\alpha$ status of the human fibroblasts was investigated using RT-PCR with PCR primers recognising sequences within regions $\mathrm{A} / \mathrm{B}$ and $\mathrm{D}$ of human ER $\alpha$ mRNA respectively. These primers produced a product of $292 \mathrm{bp}$ from the cDNA derived from MCF-7 and T47D cells. This band indicated the presence of ER $\alpha$ mRNA (Fig. 2). The negative control was the MDA-MB-231 cell line which is known not to express $\mathrm{ER} \alpha$ and with which no PCR signal was found. With cDNA from fibroblasts from either normal or malignant human breasts, no ER $\alpha$-specific band was amplified (Fig.
2). With ER $\beta$-specific primers, a PCR product of the expected size, $200 \mathrm{bp}$, was produced in all the samples from both the normal and malignant human breast fibroblasts and the two breast epithelial cell lines, MCF-7 and MDA-MB-231. It is notable that a minor but higher molecular weight PCR product was also obtained using the ER $\beta$ primers $\mathrm{F}$ and $\mathrm{B}$. This represents a splice variant with an insertion into the $\mathrm{C}$ and $\mathrm{D}$ regions, which are important for DNA binding and dimerisation.

Human breast fibroblasts were prepared from an established technique in our laboratory and their morphological appearance was examined and subsequently confirmed to be that of fibroblasts and 

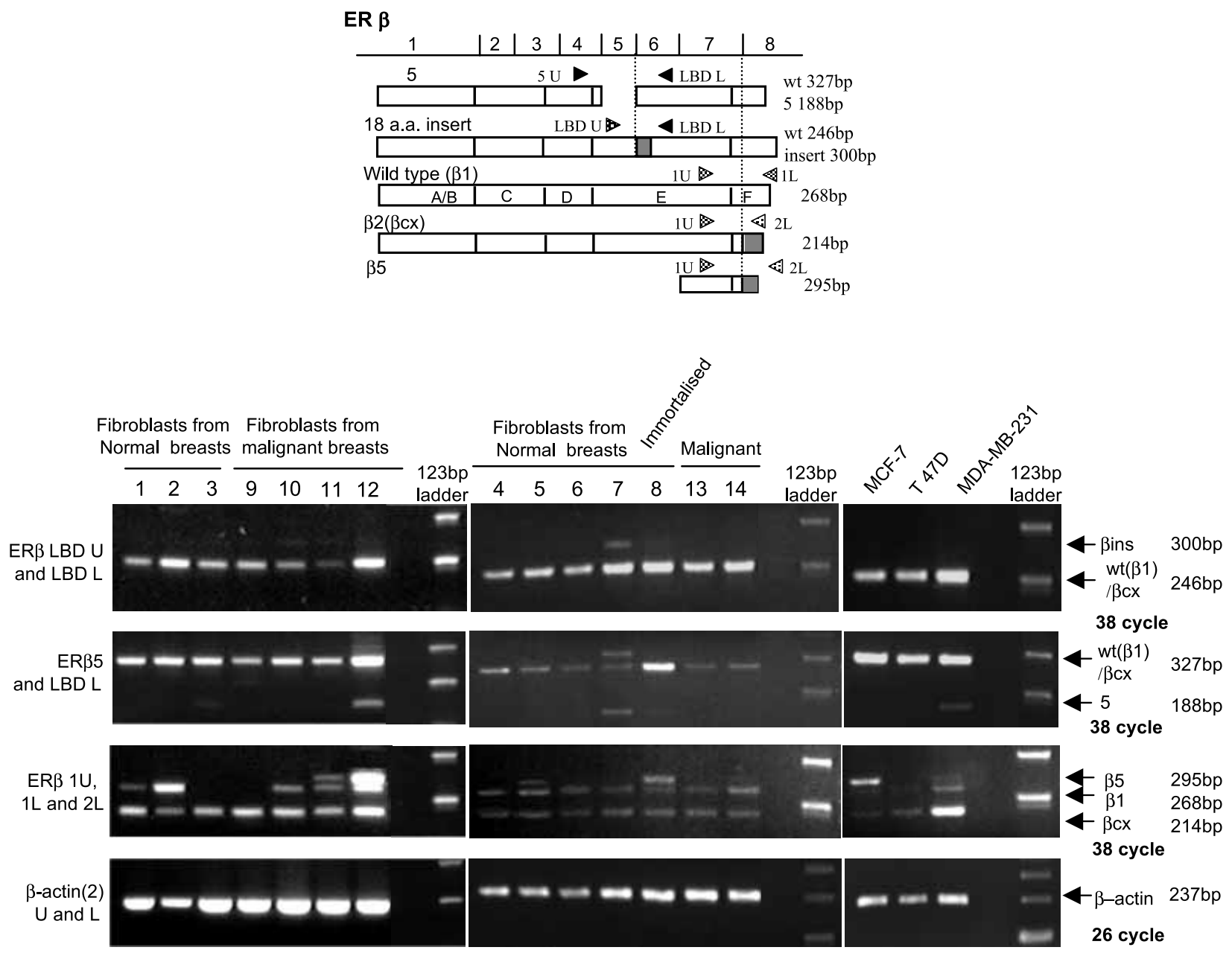

Figure 3 Expression of ER $\beta$ variants in purified breast fibroblasts and breast epithelial cancer cell lines. The expression of ER $\beta$ variants ER $\beta 1, E R \beta c x$, ER $\beta 5$ and ER $\beta$ ins mRNA transcripts in 14 normal and malignant breast fibroblasts, and the epithelial cancer cell lines MCF-7 and MDA-MB-231 was analysed by RT-PCR using splice variant-specific primers. Schematic diagrams of the structures and functional domains of common ER $\beta$ splice variants are shown in the upper panel. $\beta$-actin cDNA was amplified in parallel. a.a., amino acids; wt, wild type.

not epithelial cells. Cytokeratin 19 was used as a marker for epithelial cells to assess the degree of contamination of fibroblasts with epithelial cells. RT-PCR analysis with cytokeratin 19 primers produced a predicted product of $500 \mathrm{bp}$ from the MCF-7 and MDA-MB-231 cell lines, but not from any of the purified human breast fibroblasts, indicating that the human fibroblasts isolated were not contaminated with epithelial cells (Fig. 2).

\section{Expression of ERß variant mRNAs in human breast fibroblasts}

The expression of ER $\beta$ splice variants in populations of purified breast fibroblasts was investigated by PGR analysis (Fig. 3). Three categories of variants were investigated: ERßins-, a splice variant with an insert of $54 \mathrm{bp}$ in the ligand-binding domain (Chu et al. 1997, Petersen et al. 1998) commonly found in rodents but not in human tissues; $\mathrm{ER} \beta \delta 5$, which lacks exon 5; $\mathrm{ER} \beta \mathrm{cx}$, in which the C-terminal 61 amino acids are replaced by a unique 26 amino acid sequence; and ER $\beta 5$ which is a truncated receptor consisting only of amino acids 409-472. The 14 fibroblast samples were processed separately in two subgroups. The expression levels of various ER $\beta$ isoforms were judged by the relative intensity of the bands between different samples within the same subgroup. 
The presence of ER $\beta$ ins was examined using the primer pair LBD U and LBD L, complementary to sequences in exon 5 and exon 6 of the $E R \beta$ gene respectively. In only one cDNA sample was a band corresponding to ERßins amplified. The one positive signal seen in lane 7 could represent a novel splice variant arising from a rare human mutation.

For detection of $\mathrm{ER} \beta \delta 5$ variants, primers recognising sequences in exon 4 and exon 6 of the gene were used. The PCR result showed that in all the normal and malignant breast fibroblasts there was a normal ER $\beta$ mRNA with an intact 5 th exon. However, as revealed by the presence of the shorter $188 \mathrm{bp}$ ( $\delta 5$-specific) PCR product, the normal fibroblasts in lanes 3 and 7 as well as the malignant line 12 also expressed the ER $\beta$ splice variant which lacks the 5th exon. This ER $\beta \delta 5$ splice form was also present in the MDA-MB-231, but not the MCF 7 and T47D epithelial cell lines. It is notable that these $\delta 5$-specific primers also span the region of the ligand-binding domain and thus include the region where ERßins would be detected. The presence in the normal fibroblast in lane 7 of a PGR product about 50 bp longer than expected confirmed that there was a novel mRNA in this sample.

Detection of the ER $\beta c x$ and ER $\beta 5$ variants by PCR involved the use of three primers in the same reaction, namely $1 \mathrm{U}, 1 \mathrm{~L}$ and $2 \mathrm{~L}$, corresponding to sequences in exon 7 and in exon 8 present only in ER $\beta c x$ and ER $\beta 5$ mRNA respectively. The PCR results showed that all but two of the fibroblast cell lines possessed the ER $\beta 1 \mathrm{C}$-terminal sequence. Only the normal fibroblast (lane 3 ) and the malignant (lane 9) lacked the sequence at the 3' end of ER $\beta 1$. Interestingly, all of the human breast fibroblast lines, both normal and malignant, contained the ER $\beta \mathrm{cx}$ variant, as did the epithelial cell lines. ER $\beta 5$ transcript was only expressed in two of the six fibroblast cell lines (11 and 12) derived from malignant breast tumours and in two of the eight normal fibroblast cell lines (5 and 8) derived from normal fibroblasts.

\section{Expression of ER $\beta$ but not ER $\alpha$ protein in human breast fibroblasts}

Cell lysates were prepared from the majority of the samples and subjected to Western blot analysis for ER expression (Fig. 4). The expression of ER $\alpha$ and the two major $\mathrm{ER} \beta$ variants $(\mathrm{ER} \beta 1$ and $\mathrm{ER} \beta \mathrm{cx})$ in breast fibroblasts was investigated with specific antibodies. Western blots for ER $\alpha$ revealed that only the cell line MCF-7 expressed ER $\alpha$ of the expected molecular weight of $66 \mathrm{kDa}$. MDA-MB231 (a known ER $\alpha$-negative breast epithelial cell line) and all of the normal and malignant human breast fibroblasts were negative for ER $\alpha$. Western blot analysis with an ER $\beta$ antibody (LBD) raised against the ligand-binding domain of ER $\beta 1$ (Saji et al. 2000, 2002) identified a predominant ER $\beta$ product of $57 \mathrm{kDa}$, corresponding to $\mathrm{ER} \beta 1$, at significant levels in all but two of the fibroblasts. It is notable that the ER $\beta$ expression levels in these two fibroblast lines 3 and 9 were extremely low when compared with the other fibroblast lines. This was consistent with our previous RT-PGR results showing that both lines 3 and 9 expressed very low levels of ER $\beta 1$. Unlike ER $\beta 1, E R \beta c x$ appeared to be expressed in all breast fibroblasts studied, again consistent with the RT-PCR result. This result also demonstrated that the epithelial cell lines MCF-7 and MDA-MB-231 expressed both ER $\beta 1$ and $\mathrm{ER} \beta \mathrm{cx}$. These data confirmed that, at the protein level, human breast fibroblasts express only ER $\beta$ and not $\mathrm{ER} \alpha$.

\section{Expression of ER $\beta$ with little or no oestrogen- binding activity in breast fibroblasts}

We next examined the expression levels and binding capacity of $\operatorname{ER} \alpha$ and $\operatorname{ER} \beta$ in the human breast fibroblasts and the MCF-7 and MDA-MB231 cell lines using sucrose density gradient centrifugation assay with $\left[{ }^{3} \mathrm{H}\right]$ oestradiol as ligand (Palmieri et al. 2002). Consistent with previous data, the ER $\alpha$-containing radiolabelled $8 \mathrm{~S}$ peak was only detected in the extract from the MCF-7 cells, and not in extracts from the human breast fibroblasts or the ER $\alpha$-negative MDA-MB-231 cell line (Fig. 5). This expression pattern was confirmed by Western blotting of sucrose density gradient fractions corresponding to a sedimentation rate of $8 \mathrm{~S}$. Although it has been shown that ER $\beta$ sediments on sucrose gradients as a $4 \mathrm{~S}$ peak (Weihua et al. 2001, Palmieri et al. 2002), no specific 4S oestradiolbinding peak was observed for the human breast fibroblasts or the MCF-7 and MDA-MB-231 cell lines. Western blotting of the fractions corresponding to the $4 \mathrm{~S}$ region of the gradient 


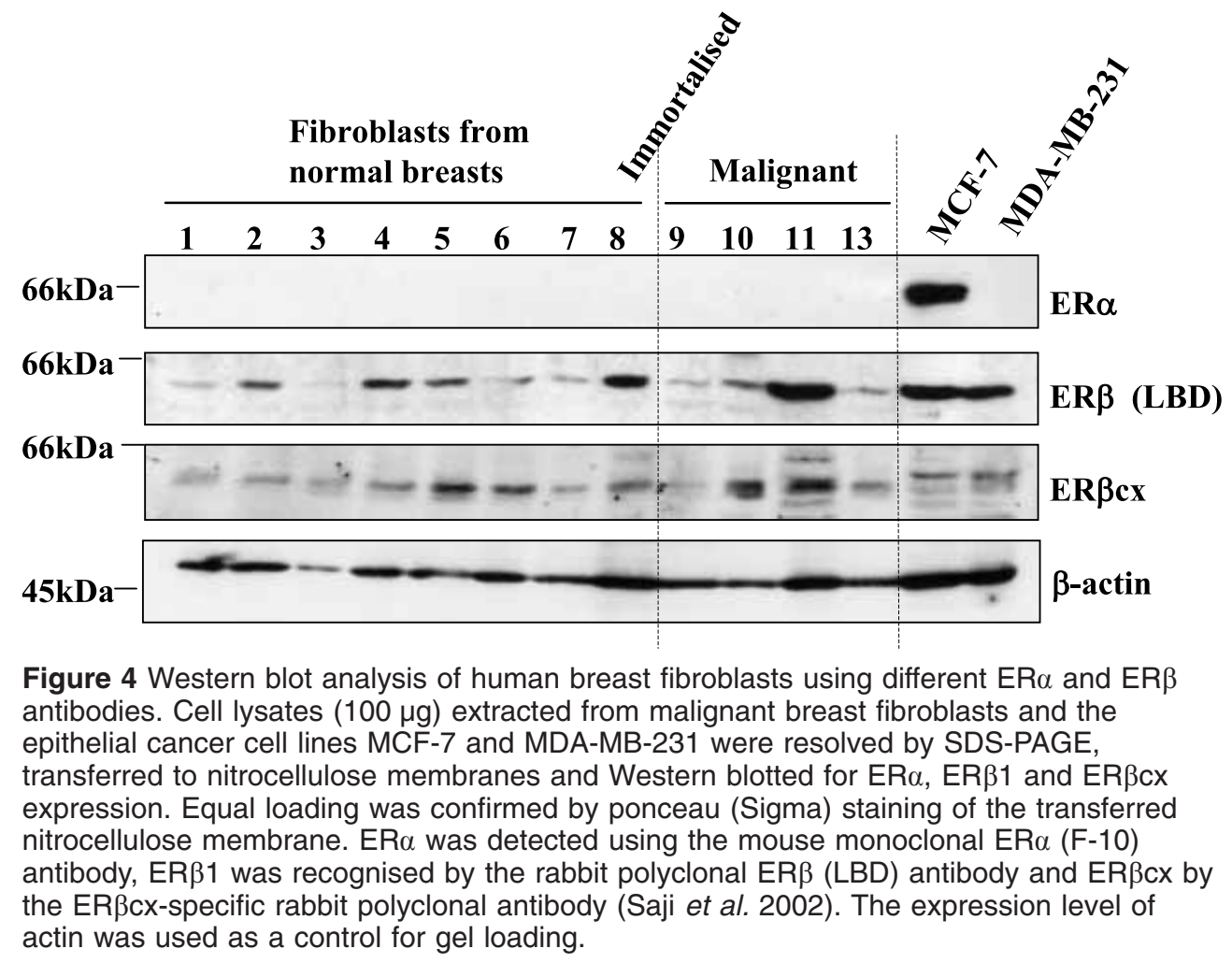

showed that ER $\beta$ was present in these fractions. One interpretation of these results is that $\operatorname{ER} \beta c x$ which does not bind oestradiol is the dominant ER in the human breast fibroblasts as well as the MCF-7 and MDA-MB-231 cell lines. When the $4 \mathrm{~S}$ sucrose gradient fractions were probed for ER $\beta \mathrm{cx}$ expression, it was found that the human breast fibroblasts and the MCF-7 and MDA-MB-231 cell lines all expressed the ER $\beta c x$ protein.

\section{Role of ER and oestrogen in adult human mammary fibroblasts}

FGF7 is a breast stromal fibroblast-derived mitogen that stimulates mammary epithelial cell growth. Previous reports have indicated that the expression of FGF7 mRNA and protein in mammary gland is oestrogen regulated (Zhang et al. 1998, Pedchenko \& Imagawa 2000). To obtain further information on the functional role of the ER species present in the human breast fibroblasts, the effects of various $\mathrm{ER} \alpha$ and $\beta$ ligands on FGF7 release from these fibroblasts were analysed by ELISA (Fig. 6.). Consistent with previous reports (Palmieri et al.
2003), treatment with IL- $1 \beta$ induced a significant increase in the release of FGF7 ( $t$-test, $P<0 \cdot 001)$, indicating that these human breast fibroblasts were capable of producing FGF7. When fibroblasts in culture were treated with various physiological concentrations of oestradiol $\left(10^{-10}, 10^{-9}, 10^{-8}\right)$, there was no significant increase in release of FGF7 into the culture medium. Similarly, the antioestrogens tamoxifen and ICI 182,780 had little effect on the release of FGF7. This is in agreement with the earlier sucrose gradient oestradiol-affinity assay showing that the ER $\beta$ in human breast fibroblasts has little oestrogen-binding activity. Interestingly, when the breast fibroblasts were incubated with the ER $\beta$-selective ligand, BAG (Cheng et al. 2004), which has $100 \times$ higher affinity for $E R \beta$ compared with ER $\alpha$, significant levels of FGF7 release were observed $(t$-test, $P<0 \cdot 001)$. Similarly, another ligand, kaempferol (Kuiper et al. 1998), which has been demonstrated to have high affinity for ER $\beta$, also increased FGF7 production in human breast fibroblasts $(t$-test, $P<0 \cdot 001)$. We next transfected into these breast fibroblasts an ERE-responsive reporter construct to assay for ERE-dependent transcriptional activity in the 


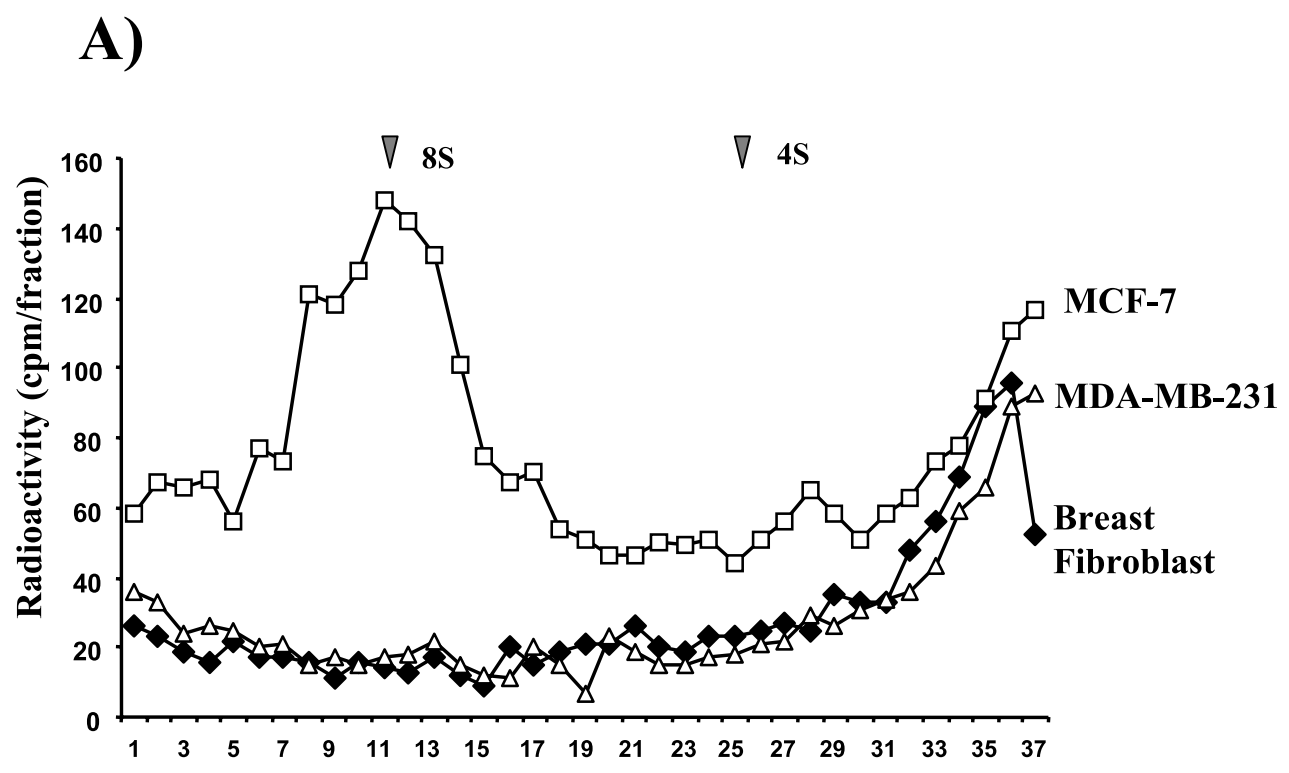

\section{Sucrose gradient fractions}

B)

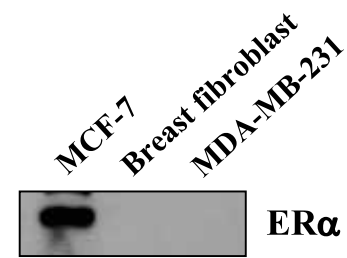

Fractions 6-20

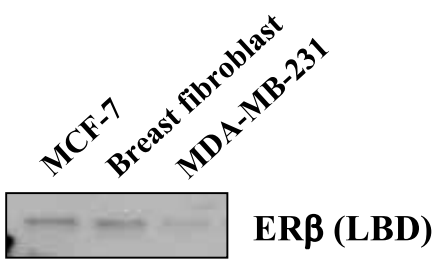

$\operatorname{ER} \beta c x$

Fractions 24-30

Figure 5 Total ligand-binding sucrose density gradient and Western blot analysis of human breast fibroblast, MCF-7 and MDA-MB-231 cell lysates. Human breast fibroblast, MCF-7 and MDA-MB-231 cell lysates were subjected to sucrose density gradient assay using $\left[{ }^{3} \mathrm{H}\right]$ oestradiol as ligand. Fractions $(100 \mu \mathrm{l})$ were collected from the bottom of the gradients and assayed for radioactivity by liquid scintillation counting. A representative typical human breast fibroblast reactivity profile is shown (A). Parallel control gradients for human breast fibroblast, MCF-7 and MDA-MB-231 were performed in the presence of 50-fold excess unlabelled oestradiol. These profiles overlapped with those of MDA-MB-231 and human breast fibroblasts (data not shown). Fractions corresponding to sedimentation rates of $8 S$ (fractions 6-20) and 4S (fractions 24-30) were pooled and subjected to Western blot analysis for ER $\alpha$, ER $\beta 1$ (using LBD antibody) and ER $\beta c x$ expression (B).

presence of oestradiol and BAG. The results showed that while oestrogen failed to significantly transactivate the ERE-dependent reporter ( $t$-test, $P=0 \cdot 064)$, BAG could activate transcription from this construct ( $t$-test, $P=0 \cdot 006)$. These findings supported the notion that human breast fibroblasts express $\operatorname{ER} \beta$ but not $\operatorname{ER} \alpha$, and that $\operatorname{ER} \beta$ species present in the human breast fibroblasts have low oestradiol-binding activity and little function in oestrogen action. 
A)

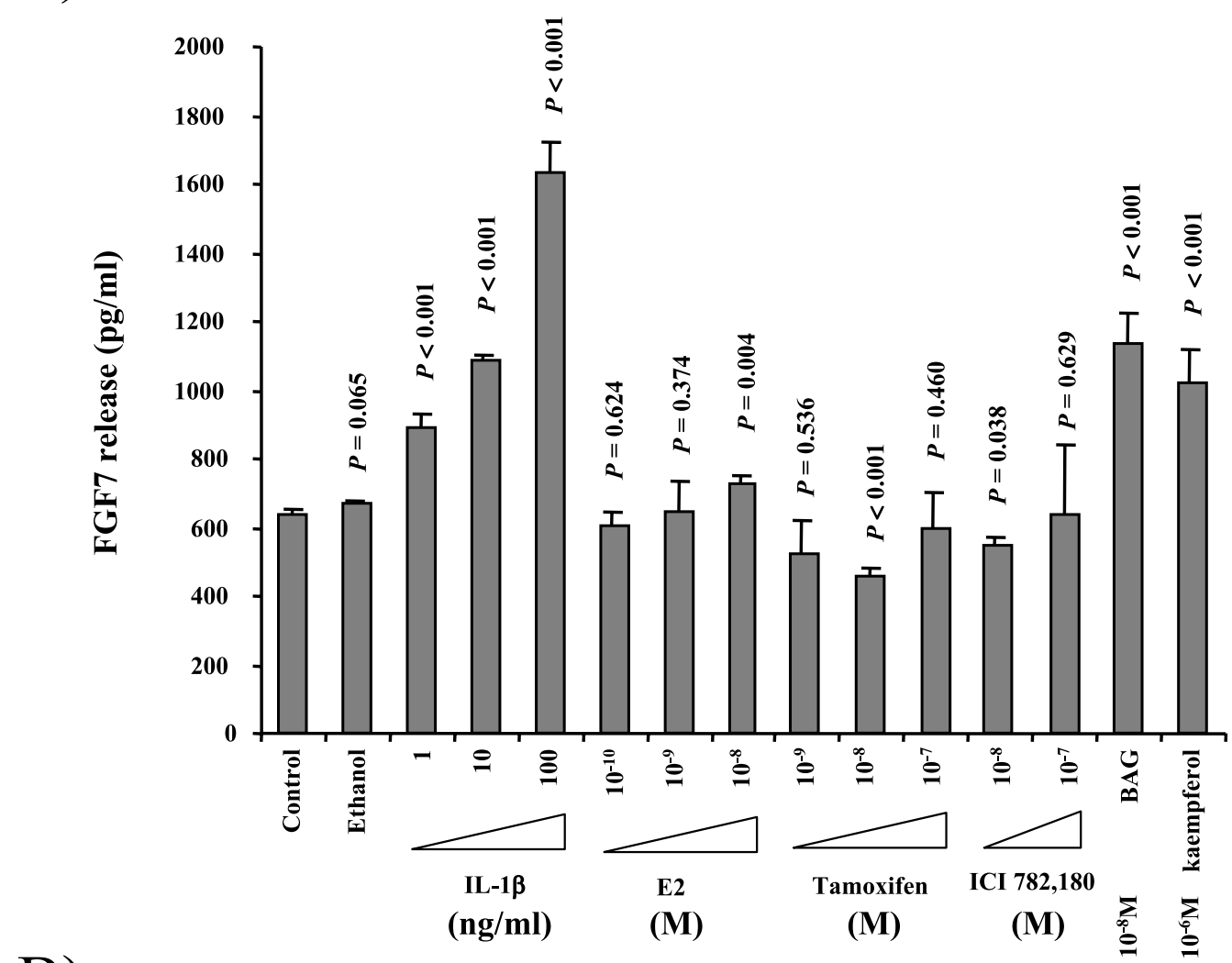

B)

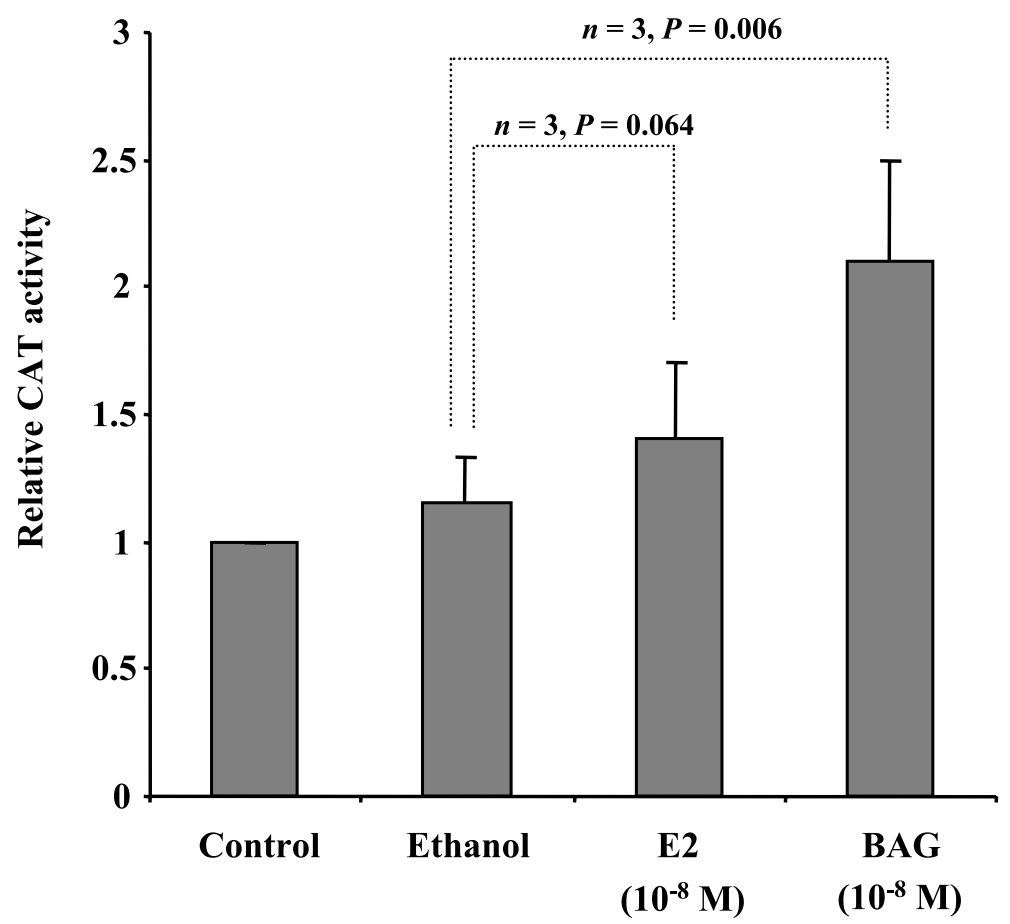




\section{Discussion}

Our previous immunohistochemical studies have suggested that $\mathrm{ER} \beta$ but not $\mathrm{ER} \alpha$ is expressed in human breast stroma (Jensen et al. 2001, Palmieri et al. 2002). In the present study, we further confirmed this observation with more detailed immunohistochemical staining, using additional breast tissue samples and ER $\beta$-specific antibodies. More importantly, using purified populations of adult female human breast fibroblasts, we went on to study the expression of $\operatorname{ER} \alpha$ and $\operatorname{ER} \beta$ using RT-PGR, Western blot analysis and sucrose density gradient assay, and again found that $\operatorname{ER} \beta$ but not $\mathrm{ER} \alpha$ was expressed in both normal and malignant human breast fibroblasts. This is the first time that purified populations of breast fibroblasts have been analysed for their $\operatorname{ER} \alpha$ and $\operatorname{ER} \beta$ content and unique information is provided regarding the expression of $\operatorname{ER} \beta$ variants in human breast fibroblasts. We have previously found a predominant expression of $\mathrm{ER} \beta \mathrm{cx}$, a splice variant which does not bind oestrogen, and which is a dominant repressor of $\mathrm{ER} \alpha$ with less effect on $\mathrm{ER} \beta 1$ (Ogawa et al. 1998).

At first glance, the absence of ER $\alpha$ from breast stroma might seem to be in conflict with some published data (Boyd et al. 1996, Keeling et al. 2000, Koerner et al. 2001), but it appears that several studies showing the presence of ER $\alpha$ in human breast stroma were done on developing gland, fetal, newborn or young female individuals (Keeling et al. 2000) and this prompts us to speculate that ER $\alpha$ is expressed in the stroma of the developing gland and that there is a switch to $\mathrm{ER} \beta$ as the gland matures. Consistent with this explanation, Boyd et al. (1996) noted that the number of fibroblasts positive for $\mathrm{ER} \alpha$ decreased as the glandular tissue became more differentiated/ mature, and Koerner et al. (2001) found that $\mathrm{ER} \alpha$-positive fibroblasts were more readily detectable in young teenage females compared with older subjects. In the rat mammary gland, administration of growth hormone has been shown to result in expression of ER $\alpha$ in mammary stromal cells (Feldman et al. 1999). Although at present there are no data on the regulation of the human stromal $\mathrm{ER} \alpha$, it is possible that stimulation by growth hormone, or another hormone expressed during periods of growth of the organism, may explain these age-related phenomena, and aberrant expression of these stochastic factors could account for some of the instances when $\mathrm{ER} \alpha$ has been found in the stroma of adult human breast.

Previous studies using mouse models have shown that epithelial-stromal cell interactions are important for the normal development and function of the mammary gland. Cuhna et al. (1997) have found that the growth of mammary ducts in mice requires the presence of ER in the stroma. In addition, it has been shown that the effects of oestrogen on proliferation in the mammary epithelium of mice are modulated by the mammary stroma (Woodward et al. 1998), and a similar observation has been documented in the uterus (Cooke et al. 1997). A possible mechanism for the effect of oestrogen on the mammary epithelium which is mediated by the stroma has been put forward recently by Zhang et al. (2002). These authors found that treatment of murine fibroblasts with oestrogen caused an increase in the production of $\mathrm{HGF}$, which caused proliferation of epithelial cells. In light of the present finding that $\operatorname{ER} \beta$ but not $\mathrm{ER} \alpha$ is expressed in adult human breast fibroblasts, the mesenchymal-epithelial relationship as well as the possible effects of oestrogen acting indirectly on

Figure 6 Effect of various cytokines and ER ligands and agonists on the release of FGF7 and ERE-dependent transactivation activity by breast fibroblasts. (A) Purified breast fibroblasts were incubated with different concentrations of IL-1 $\beta$, oestrogen, ICI 182,780, tamoxifen, BAG and kaempferol for 3 days, and the level of FGF7 release into the culture medium assayed using ELISA. Since most compounds were dissolved in ethanol, ethanol was also included as a control. Each point represents the means \pm S.E.M. with $n=6$. Further statistical analysis was performed using $t$-tests between the control and each individual treatment, and $P$ values are shown above each histogram. (B) Transcription activity of an ERE-responsive reporter plasmid was analysed in human breast fibroblasts in response to oestradiol and BAG treatment. An ERE-responsive promoter CAT reporter construct was transfected into human breast fibroblasts and then analysed for CAT activity 3 days later. The CAT activity was normalised with $\beta$-galactosidase activity from a co-transfected control plasmid, and the relative activity calculated, as was the fold induction. The data shown are representative of three independent experiments, and error bars represent the S.E.M. of the data. Statistical analysis was performed using $t$-tests between the ethanol control and each individual treatment, and the $P$ values are shown. 
the epithelium via stromal ER also need to be re-evaluated. Moreover, the present data indicate that some of the previous studies on mouse stroma-epithelium interactions may not be applicable to the adult human breast situation.

Besides demonstrating that $\operatorname{ER} \beta$ is the sole ER isotype expressed in breast fibroblasts, our RT-PCR and Western blotting results also showed that $\operatorname{ER} \beta 1$ and $\operatorname{ER} \beta c x$ are the predominant variants in breast fibroblasts, with $\mathrm{ER} \beta \mathrm{cx}$ expressed in all fibroblasts examined and ER $\beta 1$ in all but two of the fibroblasts. It is interesting to note that $\mathrm{ER} \beta \mathrm{cx}$ was expressed at a higher frequency in these human breast fibroblasts than ER $\beta 1$, suggesting that $\mathrm{ER} \beta \mathrm{cx}$ could be the major form of $\mathrm{ER} \beta$ in breast fibroblasts. The other variants, including ER $\beta 5$ and $\operatorname{ER} \beta \delta 5$, were also detected in the fibroblasts, but they were present at low levels in human breast fibroblasts. Our result also identified a potential rare insertion variant present in one of the fibroblast cell lines (line 7); however, its functional significance requires further investigation. No significant difference in $\operatorname{ER} \beta$ variant expression was observed between normal and malignant fibroblasts. Although ERßins is frequently expressed in rat mammary glands (Saji et al. 2001), our data showed that it is not normally detected in either normal or malignant human breast fibroblasts. It has been proposed that human $E R \beta c x$ has a role similar to that suggested for ERßins in rat mammary glands, which is to antagonise ER $\alpha$ activity (Saji et al. 2001).

Previous studies have shown that $\mathrm{ER} \beta \mathrm{cx}$ is expressed in breast cancer (Chu et al. 1997, Petersen et al. 1998, Omoto et al. 2002, Palmieri et al. 2002). However, there have been diverse reports regarding the potential role of ER $\beta c x$. Some evidence has shown that high levels of ER $\beta c x$ mRNA expression are associated with tamoxifenresistant and more aggressive breast cancers (Leygue et al. 1999, Speirs et al. 1999, Saji et al. 2002). In contrast, a reduced expression of ER $\beta c x$ has been reported to be associated with metastatic breast tumours and those that have a high number of tumour-positive lymph nodes (Ahr et al. 2001, 2002). Moreover, vascular invasion has also been found to correlate significantly with an ER $\beta c x-$ negative phenotype (Saji et al. 2002) and, recently, $\mathrm{ER} \beta \mathrm{cx}$ expression has been associated with favourable response to endocrine therapy and prognostic outcome (Palmieri et al. 2004). The selective expression of ER $\beta \mathrm{cx}$ strongly suggests that splicing of the $E R \beta$ gene is regulated in a cell-specific manner. This is not the first report in which $\mathrm{ER} \beta \mathrm{cx}$ and/or $\mathrm{ER} \beta 1$ are expressed in populations of cells where there is no ER $\alpha$. In the endometrium, $\mathrm{ER} \beta \mathrm{cx}$ protein and RNA were expressed in decidual glands and stroma cells in the absence of ER $\alpha$ (Henderson et al. 2003) and in Sertoli cells of the testis there was expression of ER $\beta c x$ but not ER $\beta 1$ (Saunders et al. 2002).

In the present study, ER $\beta c x$ appears to be the predominant form of $\mathrm{ER} \beta$ in fibroblasts from both normal and malignant adult mammary glands. Previous in vitro studies have shown that it is a very good repressor of ER $\alpha$ function at EREs (Ogawa et al. 1998) but the activity of ER $\beta c x$ alone or in combination with either $\operatorname{ER} \alpha$ or $\operatorname{ER} \beta$ at 'nonclassical' oestrogen-responsive sites, such as AP-1 and Spl, has not been investigated (Paech et al. 1997). Since ERs mediate proliferation as well as differentiation, a more thorough look at which functions of $\mathrm{ER} \alpha$ are influenced by $\mathrm{ER} \beta \mathrm{cx}$ is needed in order to define the physiological role of $\mathrm{ER} \beta \mathrm{cx}$. In the present study, there was no detectable $\mathrm{ER} \alpha$ in breast stroma. If $\operatorname{ER} \beta \mathrm{cx}$ has a physiological function in the stroma, that function is not to inhibit $\mathrm{ER} \alpha$ activity. The oestrogenbinding assay revealed that the forms of ER $\beta$ present in the $4 \mathrm{~S}$ region of the sucrose gradient do not bind efficiently to radiolabelled oestradiol. This lack of oestrogen binding supports the PCR data that $\mathrm{ER} \beta \mathrm{cx}$, which has little or no oestrogenbinding activity, is more abundant than ER $\beta 1$ and indicates that $\mathrm{ER} \beta \mathrm{cx}$ may antagonise $\mathrm{ER} \beta 1$ activity. Consistent with this, we obtained data from transient transfection assays showing that oestrogen is inefficient in activating gene transcription from an ERE-containing reporter in the human breast fibroblasts, while the same promoter can be induced by BAG, an ER $\beta$-specific ligand. Similarly, our data also showed that BAG, but not oestrogen, can induce the production of FGF7 from these fibroblasts.

The findings by Omoto et al. (1998) and Ogawa et al. (1998) that ER $\alpha$ function can be quenched by $\mathrm{ER} \beta \mathrm{cx}$ raised the question as to whether measurement of ER $\beta c x$ should be done as part of the diagnosis in breast cancer since it could identify some ER $\alpha$-positive cancers which are resistant to tamoxifen. The present finding that ER $\beta \mathrm{cx}$ is also expressed in breast stroma means that for such 
measurements to be of value, not only the expression level but also the cellular distribution of ER $\beta$ and variants would have to be considered in future diagnosis and studies of the human breast. Further studies on the regulation of $\operatorname{ER} \beta$ splice variant expression and function in the stromal compartment will help in our understanding of mammary gland development and malignant transformation, and assist in the identification of novel targets for therapeutic intervention.

\section{Acknowledgements}

This research was supported by grants from the Cancer Research-UK and the Swedish Cancer Fund. We also wish to thank Christina Thulin-Andersson for skilful technical assistance.

\section{References}

Ahr A, Holtrich U, Solbach C, Scharl A, Strebhardt K, Karn T \& Kaufmann M 2001 Molecular classification of breast cancer patients by gene expression profiling. Fournal of Pathology 195 312-320.

Ahr A, Karn T, Solbach C, Seiter T, Strebhardt K, Holtrich U \& Kaufmann M 2002 Identification of high risk breast-cancer patients by gene expression profiling. Lancet 359 131-132.

Ali S, Metzger D, Bornert JM \& Chambon P 1993 Modulation of transcriptional activation by ligand-dependent phosphorylation of the human oestrogen receptor A/B region. EMBO fournal 12 $1153-1160$

Bocchinfuso WP \& Korach KS 1997 Mammary gland development and tumorigenesis in estrogen receptor knockout mice. Fournal of Mammary Gland Biology Neoplasia 2 323-334.

Boyd M, Hildebrandt RH \& Bartow SA 1996 Expression of the estrogen receptor gene in developing and adult human breast. Breast Cancer Research and Treatment 37 243-251.

Brzozowski AM, Pike AC, Dauter Z, Hubbard RE, Bonn T, Engstrom O, Ohman L, Greene GL, Gustafsson JA \& Carlquist M 1997 Molecular basis of agonism and antagonism in the oestrogen receptor. Nature 389 753-758.

Chen D, Pace PE, Coombes RC \& Ali S 1999 Phosphorylation of human estrogen receptor alpha by protein kinase A regulates dimerization. Molecular and Cellular Biology 19 1002-1015.

Cheng G, Weihua Z, Warner M, Gustafsson JA, Strom A, Hartman J, Foster JS, Kietz S \& Wimalasena J 2004 Estrogen receptors $\mathrm{ER} \alpha$ and $\mathrm{ER} \beta$ in proliferation in the rodent mammary gland. PNAS $1013739-3746$.

Chu S \& Fuller PJ 1997 Identification of a splice variant of the rat estrogen receptor B gene. Molecular and Cellular Endocrinology 132 195-199.

Cooke PS, Buchanan DL, Young P, Setiawan T, Brody J, Korach KS, Taylor J, Lubahn DB \& Cunha GR 1997 Stromal estrogen receptors mediate mitogenic effects of estradiol on uterine epithelium. PNAS 94 6535-6540.

Crandall DL, Busler DE, Novak TJ, Weber RV \& Kral JG 1998 Identification of estrogen receptor $\beta$ RNA in human breast and abdominal subcutaneous adipose tissue. Biochemical and Biophysical Research Communications 248 523-526.
Cunha GR, Young P, Hom YK, Cooke PS, Taylor JA \& Lubahn DB 1997 Elucidation of a role for stromal steroid hormone receptors in mammary gland growth and development using tissue recombinants. Fournal of Mammary Gland Biology Neoplasia 2 393-402.

Feldman M, Ruan W, Tappin I, Wieczorek R \& Kleinberg DL 1999 The effect of GH on estrogen receptor expression in the rat mammary gland. Fournal of Endocrinology 163 515-522.

Girdler F \& Brotherick I 2000 The oestrogen receptors (ER alpha and ER beta) and their role in breast cancer: a review. Breast 9 194-200.

Gomm JJ, Browne PJ, Coope RC, Liu QY, Buluwela L \& Coombes RC 1995 Isolation of pure populations of epithelial and myoepithelial cells from the normal human mammary gland using immunomagnetic separation with Dynabeads. Analytical Biochemistry 226 91-99.

Gomm JJ, Coope RC, Browne PJ \& Coombes RC 1997 Separated human breast epithelial and myoepithelial cells have different growth factor requirements in vitro but can reconstitute normal breast lobuloalveolar structure. Fournal of Cellular Physiology 171 $11-19$.

Haslam SZ \& Shyamala G 1981 Relative distribution of estrogen and progesterone receptors among the epithelial, adipose, and connective tissue components of the normal mammary gland. Endocrinology 108 825-830.

Henderson TA, Saunders PT, Moffett-King A, Groome NP \& Critchley HO 2003 Steroid receptor expression in uterine natural killer cells. Fournal of Clinical Endocrinology and Metabolism $\mathbf{8 8}$ 440-449.

Jensen EV, Suzuki T, Kawashima T, Stumpf WE, Jungblut PW \& DeSombre ER 1968 A two-step mechanism for the interaction of estradiol with rat uterus. PNAS $\mathbf{5 9} 632-638$.

Jensen EV, Cheng G, Palmieri C, Saji S, Makela S, Van Noorden S, Wahlstrom T, Warner M, Coombes RC \& Gustafsson JA 2001 Estrogen receptors and proliferation markers in primary and recurrent breast cancer. PNAS 98 15197-15202.

Keeling JW, Ozer E, King G \& Walker F 2000 Oestrogen receptor alpha in female fetal, infant, and child mammary tissue. Fournal of Pathology 191 449-451.

Koerner F, Oyama T, Kurosumi M \& Maluf H 2001 Ovarian hormone receptors in human mammary stromal cells. Fournal of Steroid Biochemistry and Molecular Biology 78 285-290.

Kuiper GG, Enmark E, Pelto-Huikko M, Nilsson S \& Gustafsson JA 1996 Cloning of a novel receptor expressed in rat prostate and ovary. PNAS 93 5925-5930.

Kuiper GG, Lemmen JG, Carlsson B, Corton JC, Safe SH, van der Saag PT, van der Burg B \& Gustafsson JA 1998 Interaction of estrogenic chemicals and phytoestrogens with estrogen receptor beta. Endocrinology $1394252-4263$.

Lam EW-F, Bennett JD \& Watson RJ 1995 Cell-cycle regulation of human B-myb transcription. Gene 160 277-281.

Leygue E, Dotzlaw H, Watson PH \& Murphy LC 1999 Expression of estrogen receptor betal, beta2, and beta 5 messenger RNAs in human breast tissue. Cancer Research 59 1175-1179.

Nilsson S, Makela S, Treuter E, Tujague M, Thomsen J, Andersson G, Enmark E, Pettersson K, Warner M \& Gustafsson JA 2001 Mechanisms of estrogen action. Physiological Revieres 81 1535-1565.

Niranjan B, Buluwela L, Yant J, Perusinghe N, Atherton A, Phippard D, Dale T, Gusterson B \& Kamalati T 1995 HGF/SF: a potent cytokine for mammary growth, morphogenesis and development. Development 121 2897-2908.

Ogawa S, Inoue S, Watanabe T, Orimo A, Hosoi T, Ouchi Y \& Muramatsu M 1998 Molecular cloning and characterization of human estrogen receptor betacx: a potential inhibitor of estrogen action in human. Nucleic Acids Research 26 3505-3512.

O'Hare MJ, Bond J, Clarke C, Takeuchi Y, Atherton AJ, Berry C, Moody J, Silver AR, Davies DC, Alsop AE, Neville AM \& Jat PS 
2001 Conditional immortalization of freshly isolated human mammary fibroblasts and endothelial cells. PNAS 98 646-651.

Omoto Y, Kobayashi S, Inoue S, Ogawa S, Toyama T, Yamashita H, Muramatsu M, Gustafsson JA \& Iwase H 2002 Evaluation of oestrogen receptor beta wild-type and variant protein expression, and relationship with clinicopathological factors in breast cancers. European Fournal of Cancer 38 380-386.

Paech K, Webb P, Kuiper GG, Nilsson S, Gustafsson J, Kushner PJ \& Scanlan TS 1997 Differential ligand activation of estrogen receptors ERalpha and ERbeta at AP1 sites. Science 277 1508-1510.

Palmieri C, Cheng GJ, Saji S, Zelada-Hedman M, Warri A, Weihua Z, Van Noorden S, Wahlstrom T, Coombes RC, Warner M \& Gustafsson JA 2002 Estrogen receptor beta in breast cancer. Endocrine-Related Cancer 9 1-13.

Palmieri C, Roberts-Clark D, Assadi-Sabet A, Coope RC, O'Hare M, Sunters A, Hanby A, Slade MJ, Gomm JJ, Lam EW \& Coombes RC 2003 Fibroblast growth factor 7, secreted by breast fibroblasts, is an interleukin-1 beta-induced paracrine growth factor for human breast cells. Fournal of Endocrinology 177 65-81.

Palmieri C, Lam EW, Mansi J, MacDonald C, Shousha S, Madden P, Omoto Y, Sunters A, Warner M, Gustafsson JA \& Coombes RG 2004 The expression of ERbetacx in human breast cancer and the relationship to endocrine therapy and survival. Clinical Cancer Research 10 2421-2428.

Parker MG 1998 Transcriptional activation by oestrogen receptors. Biochemical Society Symposium 63 45-50.

Parmar H, Young P, Emerman JT, Neve RM, Dairkee S \& Cunha GR 2002 A novel method for growing human breast epithelium in vivo using mouse and human mammary fibroblasts. Endocrinology 143 4886-4896.

Pedchenko VK \& Imagawa W 2000 Estrogen treatment in vivo increases keratinocyte growth factor expression in the mammary gland. Fournal of Endocrinology 165 39-49.

Petersen DN, Tkalcevic GT, Koza-Taylor PH, Turi TG \& Brown TA 1998 Identification of estrogen receptor $\beta 2$, a functional variant of estrogen receptor $\beta$ expressed in normal rat tissues. Endocrinology 139 1082-1092.

Saji S, Jensen EV, Nilsson S, Rylander T, Warner M \& Gustafsson JA 2000 Estrogen receptors alpha and beta in the rodent mammary gland. PNAS 97 337-342.

Saji S, Sakaguchi H, Andersson S, Warner M \& Gustafsson J 2001 Quantitative analysis of estrogen receptor proteins in rat mammary gland. Endocrinology 142 3177-3186.

Saji S, Omoto Y, Shimizu C, Warner M, Hayashi Y, Horiguchi S, Watanabe T, Hayashi S, Gustafsson JA \& Toi M 2002 Expression of estrogen receptor (ER) (beta)cx protein in $\mathrm{ER}($ alpha)-positive breast cancer: specific correlation with progesterone receptor. Cancer Research 62 4849-4853.
Sasano H, Suzuki T, Matsuzaki Y, Fukaya T, Endoh M, Nagura H \& Kimura M 1999 Messenger ribonucleic acid in situ hybridization analysis of estrogen receptors alpha and beta in human breast carcinoma. Fournal of Clinical Endocrinology and Metabolism 84 781-785.

Saunders PT, Millar MR, Macpherson S, Irvine DS, Groome NP, Evans LR, Sharpe RM \& Scobie GA 2002 ERbetal and the ERbeta2 splice variant (ERbetacx/beta2) are expressed in distinct cell populations in the adult human testis. Fournal of Clinical Endocrinology and Metabolism 87 2706-2715.

Speirs V, Malone C, Walton DS, Kerin MJ \& Atkin SL 1999 Increased expression of estrogen receptor beta mRNA in tamoxifen-resistant breast cancer patients. Cancer Research $\mathbf{5 9}$ $5421-5424$.

Sunil N, Bennett JM \& Haslam SZ 2002 Hepatocyte growth factor is required for progestin-induced epithelial cell proliferation and alveolar-like morphogenesis in serum-free culture of normal mammary epithelial cells. Endocrinology 143 2953-2960.

Walker KJ, McClelland RA, Candlish W, Blamey RW \& Nicholson RI 1992 Heterogeneity of oestrogen receptor expression in normal and malignant breast tissue. European Fournal of Cancer 28 34-37.

Weihua Z, Makela S, Andersson LC, Salmi S, Saji S, Webster JI, Jensen EV, Nilsson S, Warner M \& Gustafsson J-A 2001 A role for estrogen receptor $\beta$ in the regulation of growth of the ventral prostate. PNAS 98 6330-6335.

Woodward TL, Xie JW \& Haslam SZ 1998 The role of mammary stroma in modulating the proliferative response to ovarian hormones in the normal mammary gland. Fournal of Mammary Gland Biology Neoplasia 3 117-131.

Yang Y, Spitzer E, Meyer D, Sachs M, Niemann C, Hartmann G, Weidner KM, Birchmeier C \& Birchmeier W 1995 Sequential requirement of hepatocyte growth factor and neuregulin in the morphogenesis and differentiation of the mammary gland. Fournal of Cell Biology 131 215-226.

Yi ES, Shabaik AS, Lacey DL, Bedoya AA, Yin S, Housley RM, Danilenko DM, Benson W, Cohen AM, Pierce GF et al. 1995 Keratinocyte growth factor causes proliferation of urothelium in vivo. Fournal of Urology 154 1566-1570.

Zhang HZ, Bennett JM, Smith KT, Sunil N \& Haslam SZ 2002 Estrogen mediates mammary epithelial cell proliferation in serum-free culture indirectly via mammary stroma-derived hepatocyte growth factor. Endocrinology 143 3427-3434.

Zhang Y, Kulp SK, Sugimoto Y, Farrar WB, Brueggemeier RW \& Lin YG 1998 Keratinocyte growth factor (KGF) induces aromatase activity in cultured MCF-7 human breast cancer cells. Anticancer Research 18 2541-2546.

Received 18 February 2004

Accepted 26 April 2004

Made available online as an Accepted Preprint 6 May

2004 